\title{
Microbiological and Physicochemical Characterization of the Bathing Waters of Atlantic Ocean Beaches of Grand-Bassam in Côte d'Ivoire
}

\author{
Thérèse Agbessi-Kouassi ${ }^{1,2, \text { * }}$, Aubin Tchapé Gbagbo" ${ }^{1}$, Wolfgang Toussaint Yapo ${ }^{1}$, \\ Claude Bérenger Ngalemo Ngantchouko ${ }^{2}$, Carine Nina Ablé2, Philippe André Sawa Kpaibé ${ }^{1,2}$, \\ Timothée Ouassa ${ }^{2}$, Christophe Ncho Amin ${ }^{1,2}$ \\ ${ }^{1}$ Laboratory of Water and Food Analysis, National Institute of Public Hygiene, Abidjan, Côte d'Ivoire \\ ${ }^{2}$ Department of Pharmaceutical and Biological Sciences, Félix Houphouët-Boigny University, Abidjan, Côte d'Ivoire
}

\section{Email address:}

aktherese@hotmail.com (T. Agbessi-Kouassi), aubintg2007@yahoo.fr (A. T. Gbagbo), twolfgang2y@gmail.com (W. T. Yapo), moubeung@yahoo.fr (C. B. N. Ngantchouko), ablekarine@yahoo.fr (C. N. Ablé), andresawa@yahoo.fr (P. A. S. Kpaibé), timouassa@yahoo.fr (T. Ouassa), Christophe.amin@univ-fhb.edu.ci (C. N. Amin)

${ }^{*}$ Corresponding author

\section{To cite this article:}

Thérèse Agbessi-Kouassi, Aubin Tchapé Gbagbo, Wolfgang Toussaint Yapo, Claude Bérenger Ngalemo Ngantchouko, Carine Nina Ablé, Philippe André Sawa Kpaibé, Timothée Ouassa, Christophe Ncho Amin. Microbiological and Physicochemical Characterization of the Bathing Waters of Atlantic Ocean Beaches of Grand-Bassam in Côte d'Ivoire. Frontiers in Environmental Microbiology. Vol. 5, No. 4, 2019 , pp. 84-91. doi: $10.11648 /$ j.fem.20190504.11

Received: September 3, 2019; Accepted: September 25, 2019; Published: October 10, 2019

\begin{abstract}
This study aims at the Microbiological and Physicochemical Characterization of the Bathing Waters of Atlantic Ocean Beaches of Grand Bassam in Côte d'Ivoire. Waters Sampling campaigns were carried out from December 2017 to December 2018 with a monthly sample per water point (Azuretti-village and "France" neighborhood). The analysis focused on assessment of eight (8) bacteria and parasites and the determination of twenty-eight (28) organoleptic and physicochemical parameters. The results of the physicochemical assays showed that these waters were strongly mineralized with a mean of $47.3 \mathrm{mS} / \mathrm{cm}$ at Azuretti-village and "France" neighborhood. Microbiological analyses revealed presence of total coliforms (TC), thermo-tolerant coliforms (THC), Escherichia coli, Enterococcus faecalis, Pseudomonas aeruginosa, yeasts and molds. The bathing water of on the Azuretti-village beach are conform according to the Ivorian reference system (CT and CTH are respectively less than $10,000 \mathrm{CFU} / 100 \mathrm{ml}$ and $2,000 \mathrm{CFU} / 100 \mathrm{ml}$ ) throughout the campaign, only one non-compliance is noted in August on the beach of "France" neighborhood. Regarding the Algerian standard taken in addition to Ivorian criteria, the number of $E$. faecalis bacteria must be less than $100 \mathrm{CFU} / 100 \mathrm{ml}$. Based on this standard, both ranges exhibited total coliform and heat-tolerant conformities throughout the study period and did not comply with E. faecalis during the months of January to February 2018 and from June to September 2018. The Canadian and American standard stipulates only the geometric mean of $E$. faecalis which must be lower than 35. In view of this standard, these waters present $54 \%$ of non-compliance in the "France" neighborhood and 62\% of non-conformities in Azuretti-villages during the months of January to February 18 and from June to October 18. According to Algerian and Canadian standards, the bathing waters of both beaches are unsatisfactory microbiological qualities during dry and rainy periods.
\end{abstract}

Keywords: Bathing Waters, Atlantic Ocean, Microbiological Parameters, Physicochemical Parameters

\section{Introduction}

Water is a source of life. Besides uses dictated by food and hygiene, water has been used for millennia in recreational purpose. Fun and nautical activities are many and varied including swimming, canoeing, surfing [1]. Bathing plays an important social role and can be practiced at all age of life. However, the quality of bathing water is important for the health of bathers and the development of seaside tourism $[1,2]$. 
There are several categories of bathing, whether developed or not. These include coastal (seawater) or indoor (freshwater, river, lake, pond) that have specific problems related to contamination either by more or less purified sewage or runoff driving various pollutants or by anthropogenic activities $[1,3]$. Swimmers are thus exposed to chemical and biological risks associated with poor quality of bathing water or surrounding environment [2]. Côte d'Ivoire in West Africa is docked on $566 \mathrm{~km}$ at Atlantic Ocean which covers an area of $23,253 \mathrm{~km}^{2}$, or $7 \%$ of the national territory, with more than 5 million inhabitants [4]. Grand-Bassam city, the first capital of Côte d'Ivoire from 1893 to 1900 , far of $45 \mathrm{~km}$ from Abidjan is a seaside resort. Beside its historical character, the city is known for its popular beaches bordered with palm trees and extends along the Atlantic coast. It is one of the most visited coastal cities with more than 700 to 800 people per space during the weekends for its beautiful beaches [5, 6]. Since 1993, Côte d'Ivoire has a decree defining hygiene standards in the framework of sanitary control of swimming pools, landscape beaches and bathing pools open to public [7].

Up to 2019, sanitary monitoring of equipped bathing pools has not been started. To assess health risks incurred by bathers, this study aim to characterize the bathing waters of the beaches of France neighborhood and Azuretti-village of Grand-Bassam microbiologically and physicochemically.

\section{Experimental}

\subsection{Type and Setting of the Study}

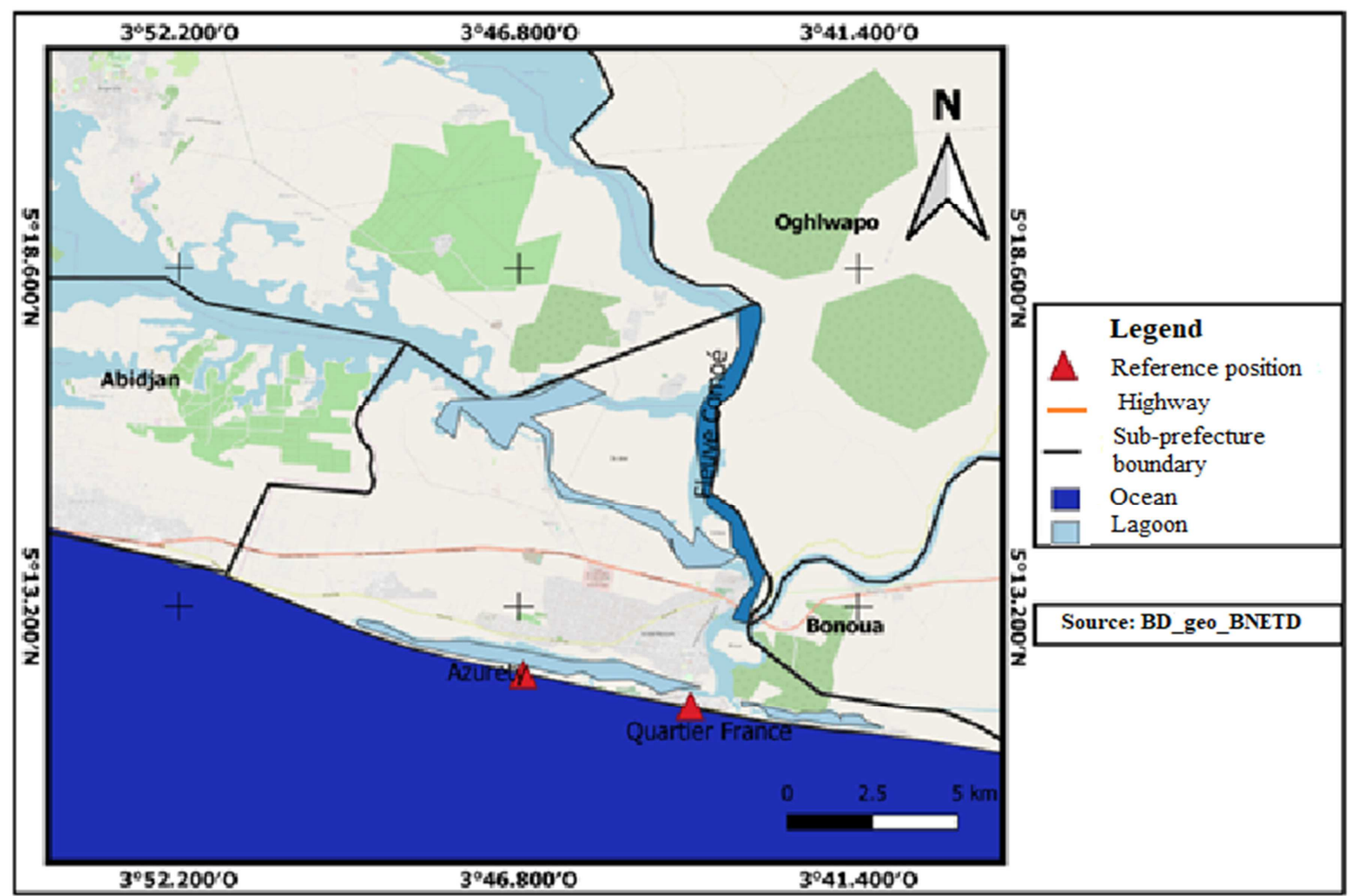

Figure 1. Mapping of the study area.

The beaches prospected quarters France neighborhood and Azuretti-village, are located in the sub-prefecture of Grand-Bassam in the south-east of Côte d'Ivoire, in the administrative region of Sud-Comoé $43 \mathrm{~km}$ from Abidjan. The city of Grand-Bassam is a coastal wetland located along the Ivorian coastline bordering the Atlantic. It is bounded in the North by the councils of Bingerville and Alépé, in the East by the Bonoua council, in the West by the council of Port-Bouët and in the South by the Atlantic Ocean. Grand-Bassam has an estimated resident population of 84,028 inhabitants and an area of $1.24 \mathrm{~km}^{2}$. Grand-Bassam is watered by three rivers namely Ebrié Lagoon, Ouladine Lagoon and Comoé River. The Ebrié Lagoon merges with the Comoé River to form the largest estuary on the Ivorian coast. This estuary is fed by the Comoé River which drains from North to South $78000 \mathrm{~km}^{2}$ of watershed according to a single flood tropical regime transition (September-October) and by the lagoon system Ebrié and the coastal rivers (Mé and Agneby) with two annual floods of unequal importance (June-July and October-November). This lagoon is the place of exchange between the continental and marine environments through the Comoé, Agneby and Mé rivers on the one hand, and the Atlantic Ocean via the Vridi canal, on the other hand [8]. The town has about 22 neighborhoods and villages including Imperial, Oddos, Mockey-city, "France" neighborhood and Azureti-village (Figure 1). 


\subsection{Sampling}

The sampling was carried out during 13 (thirteen) distinct campaigns from December 2017 to December 2018. Samples were taken in three polyethylene bottles, $1000 \mathrm{ml}$ for physicochemical parameters, $500 \mathrm{ml}$ for microbiological parameters and a $1000 \mathrm{ml}$ for the research of vibrio.

\subsection{Equipment}

The main equipment consists of a Palintest photometer (Great Britain), a pH meter (HACH HQ 11d-France), a conductivity meter (HACH HQ 14d-France), a turbidimeter (HACH HQ 14d-France), a membrane filtration device.

\subsection{Reagents}

The reagents used were of analytical quality. Reagents for measuring chemical parameters were PALINTEST ${ }^{\mathbb{B}}$ (Great Britain). The microbiology reagents consist of culture media: Rapid'E coli $2^{\circledR}$ Agar (Biorad France), Bile Esculin Agar (Biorad France), and Tryptone Sulfite Neomycin Agar (Biorad France) was used for the enumeration of markers of faecal contamination.

\subsection{Sampling, Transport and Storage of Samples}

Samples were taken according to WHO/UNEP recommendations. The samples were stored in a cool box protected from light at a temperature between $4{ }^{\circ} \mathrm{C}$ and $8^{\circ} \mathrm{C}$ and transported to the laboratory while respecting the cold chain by ice accumulators with the exception of samples intended in search of vibrio. These were transported at room temperature taking into account the fragility of the vibrio at low temperature.

\subsection{Water Analysis}

\subsubsection{Microbiological Analyzes}

Microbiological analyzes allow to identify and count total coliforms, thermo-tolerant coliforms, E. coli, Clostridiums perfringens, staphylococci, Salmonella sp, Pseudomonas and Legionella. These microorganisms were identified and counted by filtering homogeneous aliquots of $100 \mathrm{ml}$ onto a $0.45 \mu \mathrm{m}$ pore diameter membrane. The membranes were then placed on selective culture media for 24 hours at $37^{\circ} \mathrm{C}$. in a thermostated oven. The following media were used: KF agar (selective medium used for isolation and enumeration of enterococci by the conventional Petri dish counting method) for fecal Streptococci, Rapid'E. coli $2 \AA$ Agar (culture medium for the identification of Escherichia coli (EC)) for total coliforms, TSN (Tryptone Sulfite Neomycin) agar for Clostridium sulphite reducer, SS (Salmonella - Shigella) agar for salmonella, on medium pseudosel or cetrimide for Pseudomonas, on TCBS medium for Vibrio and on YGC medium for yeasts and molds.

\subsubsection{Physicochemical Analyzes}

Physicochemical parameters were determined by the following methods:
1. The $\mathrm{pH}$ is measured with a HACH type digital laboratory $\mathrm{pH}$ meter equipped with a combined electrode (Bioblock Scientific).

2. Conductivity is measured using a $\mathrm{HACH}$ type conductivity meter.

3. The turbidity is determined thanks to the $\mathrm{HACH}$ type nephelometry.

4. Titrimetry was used for the determination of organic matters.

5. Mineral salts and color were determined by colorimetry using a Palintest 7100SE photometer equipped with pre-programmed filters and calibration curves. Operational wavelengths range from $410 \mathrm{~nm}$ to $640 \mathrm{~nm}$. The procedure followed is that of the manufacturer. The desired mineral salts were potassium, nitrites, nitrates, fluorides, ortho phosphates, iron, manganese, complete alkalimetric titer (CAT), total hydrotimetric degree (THD), ammonium, aluminum, chlorides, sodium, magnesium, calcium, sulphates, potassium, bicarbonate, sulfur, zinc, phosphorus, silicates and silica.

\subsubsection{Statistical Analyzes}

The statistical analysis used is based on Principal Component Analysis (PCA). Statistical analysis was performed with 26 samples, 28 physicochemical variables and 8 microbiological variables. The study of the typology of bathing water pollution was done using a standardized Principal Component Analysis (PCA). Own values, factorial designs and total variances were obtained with the Statistica 7.1 software [8]. This made possible to process numeric characters playing the same role [9].

\section{Results and Discussion}

\subsection{Results}

\subsubsection{Microbiological Parameters}

Microbiology results of the bathing waters of the beaches of "France" neighborhood and Azuretti village of Grand-Bassam showed three groups of germs (Table 1):

1. Group 1 represented by quasi-constant microorganisms of total coliform types, thermo-tolerant coliforms, of $E$. coli and E. faecalis.

2. Group 2, the inconstant microorganisms that are Pseudomonas aeruginosa, yeasts and molds.

3. Group 3, the absent microorganisms: Salmonella, Shigella, Vibrio, Legionella and staphylococci.

These group 1 microorganisms were observed with coliform peaks of $1600 \mathrm{CFU} / 100 \mathrm{ml}$ in Azuretti-village (AV) and $3400 \mathrm{CFU} / 100 \mathrm{ml}$ in "France" neighborhood (FN) respectively in January and August. The peaks of E. faecalis were observed in January at the FN with a rate of $800 \mathrm{CFU} / 100 \mathrm{ml}$ and in September at $\mathrm{AV}$ with a rate of 900CFU/100ml (Figure 2).

\subsubsection{Organoleptic and Physicochemical Parameters}

Physicochemical results of the bathing waters of the beaches of "France" neighborhood and Azuretti-village have 
shown that these waters are highly mineralized with averages of $47.3 \mathrm{mS} / \mathrm{cm}$ (Table 2).

\subsubsection{Factor Analysis of the Beaches of "France" Neighborhood and Azuretti Village}

Tables 3 and 4 present the eigenvalues of the three (3) factors and their variances explained of the beaches of the "France" neighborhood and Azuretti village.

The factorial weights of the variables (Tables 3 and 4) reflect their correlations with the extracted factors.

Table 1. Microbiological parameters of the bathing water of the two beaches.

\begin{tabular}{|c|c|c|c|c|c|c|}
\hline \multirow{2}{*}{ Settings } & \multicolumn{3}{|c|}{ "France" neighborhood } & \multicolumn{3}{|c|}{ Azuretti village } \\
\hline & Min & Mean & Max & Min & Mean & Max \\
\hline TC & 1 & 568 & 3400 & 1 & 272 & 1600 \\
\hline THC & 1 & 545 & 3400 & 1 & 247 & 1300 \\
\hline E coli & 1 & 450 & 3400 & 1 & 131 & 930 \\
\hline E. faecalis & 1 & 114 & 800 & 1 & 241 & 900 \\
\hline P. aeruginosa & 0 & 49 & 258 & 0 & 77 & 700 \\
\hline ASR & 0 & 1 & 3 & 0 & 1 & 4 \\
\hline S. aureus & 0 & 0 & 0 & 0 & 0 & 0 \\
\hline Legionnella & 0 & 0 & 0 & 0 & 0 & 0 \\
\hline Vibrio & 0 & 0 & 0 & 0 & 0 & 0 \\
\hline Salmonella & 0 & 0 & 0 & 0 & 0 & 0 \\
\hline Molds & 0 & 3 & 36 & 0 & 1 & 16 \\
\hline Yeasts & 0 & 2 & 24 & 0 & 1 & 18 \\
\hline
\end{tabular}

TC: total coliforms; THC: thermo-tolerant coliforms.

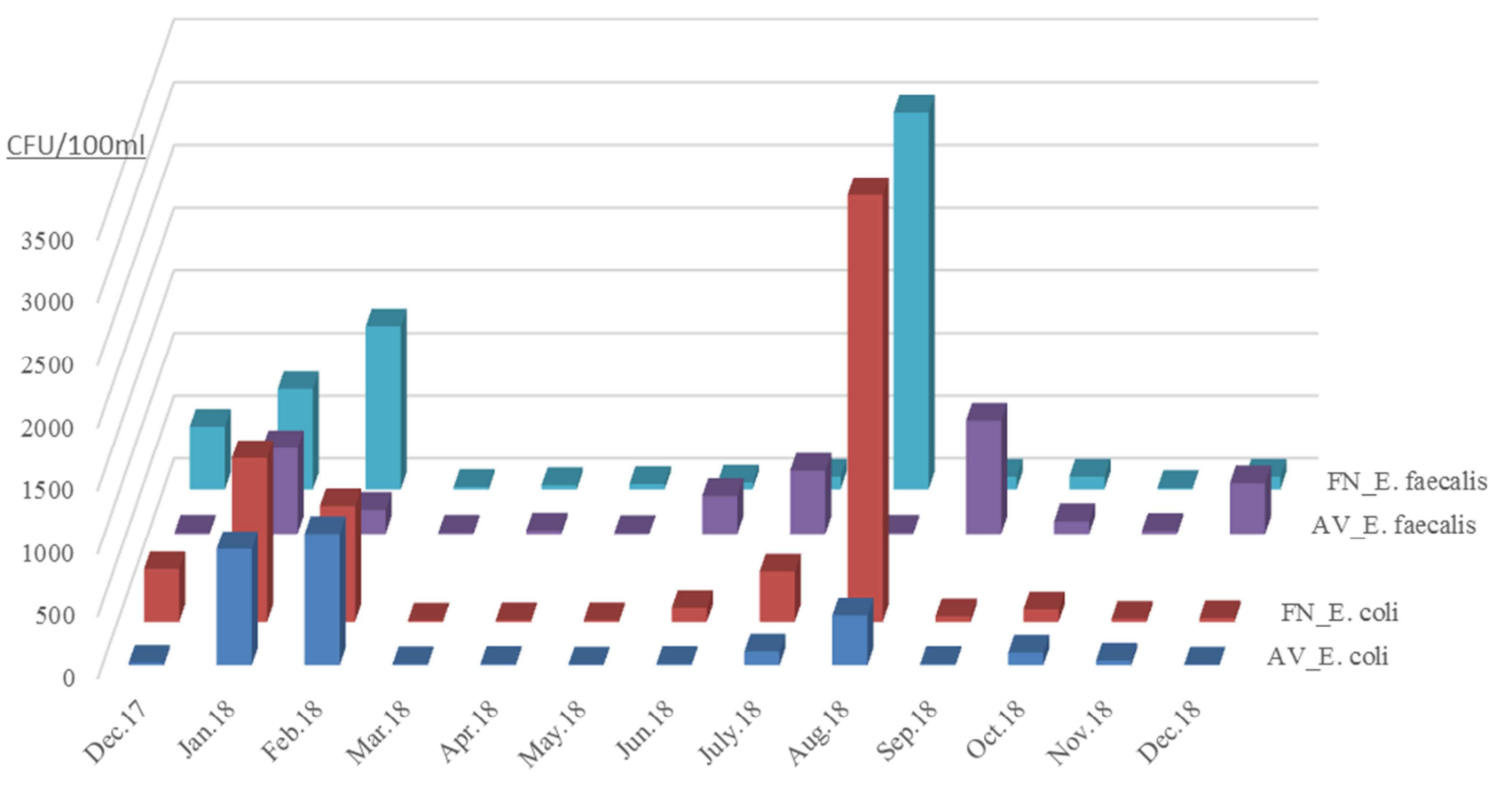

Figure 2. Histogram of microorganisms in the bathing waters of both beaches.

Table 2. Physical and chemical parameters of the bathing waters of the beaches of "France" neighborhood and Azuretti-village.

\begin{tabular}{llllll}
\hline \multirow{2}{*}{ Parameters } & "France" N. & & & Azuretti \\
\cline { 2 - 6 } & Min & Mean \pm ET & Max & Min & Mean \pm ET \\
\hline Turbidity (NTU) & 1,7 & $5,48 \pm 3,37$ & 14 & 1,73 & $5,40 \pm 2,83$ \\
Color (UCV) & 5 & $11,15 \pm 4,16$ & 15 & 5 & $11,15 \pm 4,16$ \\
Conductivity (mS/cm) & 33,2 & $47,3 \pm 6,8$ & 54,6 & 34,8 & 15 \\
pH & 6,4 & $7,78 \pm 0,67$ & 8,51 & 7,64 & $47,3 \pm 6,0$ \\
Temperature $\left({ }^{\circ} \mathrm{C}\right)$ & 24,6 & $28,80 \pm 2,25$ & 31,2 & 23,8 & $8,12 \pm 0,23$ \\
Iron (mg/L) & 0 & $0,08 \pm 0,13$ & 0,45 & 0 & $28,37 \pm 2,58$ \\
Chlorides (mg/L) & 3200 & $3730,76 \pm 471,49$ & 4800 & 3100 & $0,07 \pm 0,08$ \\
\hline
\end{tabular}




\begin{tabular}{|c|c|c|c|c|c|c|}
\hline \multirow{2}{*}{ Parameters } & \multicolumn{3}{|c|}{ "France" N. } & \multicolumn{3}{|c|}{ Azuretti } \\
\hline & Min & Mean \pm ET & Max & Min & Mean \pm ET & Max \\
\hline Nitrites (mg/L) & 0 & $0,01 \pm 0,02$ & 0,08 & 0 & $0,01 \pm 0,01$ & 0,03 \\
\hline Nitrates $(\mathrm{mg} / \mathrm{L})$ & 0,2 & $0,64 \pm 0,31$ & 1,18 & 0,24 & $0,71 \pm 0,40$ & 1,40 \\
\hline Ammonium (mg/L) & 2,2 & $6,47 \pm 2,39$ & 9,4 & 0,32 & $5,70 \pm 2,81$ & 8,90 \\
\hline Organic matters $(\mathrm{mg} / \mathrm{L})$ & 1,66 & $4,39 \pm 2,73$ & 9,70 & 1,5 & $3,99 \pm 2,47$ & 9,80 \\
\hline Phosphates $(\mathrm{mg} / \mathrm{L})$ & 0,01 & $2,07 \pm 2,44$ & 8,8 & 0,1 & $2,90 \pm 2,19$ & 6,5 \\
\hline
\end{tabular}

The first factor (F1) explains respectively the total variance of $31.68 \%$ for the beach "France" neighborhood and $37.67 \%$ for Azuretti-village. The elements incriminated by F1 are total coliforms, thermo-tolerant coliforms, Escherichia coli, yeasts and molds for both beaches. The second factor (F2) contains the Pseudomonas aeruginosa variable for two ranges. F2 explains respectively the total variance of $24.07 \%$ for the $\mathrm{FN}$ beach and $18.08 \%$ for Azuretti-village. The third factor (F3) explains respectively the total variance of $15.79 \%$ for $\mathrm{FN}$ beach and $15.11 \%$ for Azuretti-village beach. F3 contains respectively the color parameter for $\mathrm{FN}$ beach and the $\mathrm{pH}$ for the beach of Azuretti-village.

Table 3. Own values and variance of the factors of the beach France neighborhood and Azuretti-village.

\begin{tabular}{|c|c|c|c|c|c|}
\hline \multirow{2}{*}{ Location } & \multirow{2}{*}{ Factors } & \multicolumn{2}{|l|}{ Own value } & \multicolumn{2}{|c|}{$\%$ of total variance } \\
\hline & & individual & Cumulative & Individual & cumulative \\
\hline \multirow{3}{*}{ "France" N } & $\mathrm{F} 1$ & 4,11 & 4,11 & 31,68 & 31,68 \\
\hline & $\mathrm{F} 2$ & 3,12 & 7,24 & 24,07 & 55,75 \\
\hline & F3 & 2,05 & 9,30 & 15,79 & 71,55 \\
\hline \multirow{3}{*}{ Azuretti } & $\mathrm{F} 1$ & 4,89 & 4,89 & 37,67 & 37,67 \\
\hline & $\mathrm{F} 2$ & 2,35 & 7,24 & 18,08 & 55,76 \\
\hline & F3 & 1,96 & 9,21 & 15,11 & 70,87 \\
\hline
\end{tabular}

Factor extraction was performed by the principal component method. Three (3) factors whose eigenvalues are greater than 1 were selected according to the Kaiser criterion [11]. The values of $71.55 \%$ and $70.87 \%$ respectively correspond to the total variance for the "France" neighborhood and Azuretti- village.

Table 4. Factorial weights of the variable of the France neighborhood and Azuretti-village.

\begin{tabular}{|c|c|c|c|c|c|c|}
\hline \multirow{2}{*}{ Variable Settings } & \multicolumn{3}{|c|}{ Factor ("France" N) } & \multicolumn{3}{|c|}{ Factor (Azuretti) } \\
\hline & F1 & F2 & F3 & F1 & F2 & F3 \\
\hline Turbidity & 0.14 & -0.60 & -0.08 & 0.17 & 0.65 & -0.10 \\
\hline Color & -0.32 & 0.19 & -0.88 & -0.31 & -0.40 & 0.50 \\
\hline Cond & 0.00 & 0.08 & -0.64 & -0.23 & -0.47 & 0.58 \\
\hline $\mathrm{pH}$ & 0.06 & -0.30 & 0.56 & -0.07 & 0.78 & -0.22 \\
\hline $\mathrm{T}$ & 0.17 & 0.68 & 0.08 & 0.07 & -0.53 & -0.58 \\
\hline $\mathrm{TC}$ & -0.88 & -0.35 & 0.12 & -0.90 & -0.24 & -0.14 \\
\hline THCo & -0.85 & -0.41 & 0.11 & -0.85 & -0.27 & -0.10 \\
\hline$E C$ & -0.82 & -0.48 & 0.13 & -0.96 & 0.17 & 0.01 \\
\hline$E F$ & -0.68 & 0.61 & 0.13 & -0.40 & 0.44 & -0.21 \\
\hline ASR & 0.27 & 0.04 & 0.61 & -0.55 & 0.37 & 0.45 \\
\hline$P A$ & -0.43 & -0.72 & -0.25 & -0.16 & 0.38 & 0.76 \\
\hline Yeasts & -0.72 & 0.62 & 0.14 & -0.92 & 0.03 & -0.27 \\
\hline Molds & -0.73 & 0.61 & 0.12 & -0.95 & 0.07 & -0.19 \\
\hline Var. Expl. & 4.12 & 3.13 & 2.05 & 4.90 & 2.35 & 1.96 \\
\hline Prp. Tot & 0.32 & 0.24 & 0.16 & 0.38 & 0.18 & 0.15 \\
\hline
\end{tabular}

T: temperature, TC: total coliforms; THC: thermo-tolerant coliforms, EC: E. coli, EF: E. faecalis, ASR: anarobie sulfite reducteur, PA: P. qeruginosa.

\subsubsection{Comparison to Standards}

The bathing water test results showed $93.3 \%$ compliance with the FN and 100\% compliance with the Ivorian norm. The Algerian norm has the same results as the Ivorian norm at the level of TC and THC. Regarding E. faecalis, bathing waters show $15 \%$ of non-compliant with the French district and $46 \%$ of non-compliance with Azuretti-village. The Canadian and US standards focus on the geometric mean of E. faecalis which must be lower than 35 . In view of these standards, the bathing waters developed in Grand-Bassam show that 100\% of these samples analyzed are consistent with the FN. While at Azuretti-village, 0\% compliance was observed (Table 5).

Table 5. Criteria for comparison to Ivorian, Algerian, Canadian and American standards.

\begin{tabular}{lll}
\hline & \%of compliance & \\
\cline { 2 - 3 } & "France" N. & Azuretti \\
\hline Ivorian standard & & \\
pH 6-9 & 100 & 100 \\
TC $\leq 10,000$ UFC $/ 100 \mathrm{ml}$ & 100 & 100 \\
\hline
\end{tabular}




\begin{tabular}{lll}
\hline & \% of compliance & \\
\cline { 2 - 3 } & "France" N. & Azuretti \\
\hline THC $\leq 2,000 \mathrm{UFC} / 100 \mathrm{ml}$ & 93.3 & 100 \\
Sample $(\mathrm{n}=13)$ & 93.3 & 100 \\
Algerian standards & & 100 \\
pH 6-9 & 100 & 100 \\
TC $\leq 10,000 \mathrm{UFC} / 100 \mathrm{ml}$ & 100 & 100 \\
THC $\leq 2,000 \mathrm{UFC} / 100 \mathrm{ml}$ & 93.3 & 46 \\
EF $\leq 100 \mathrm{UFC} / 100 \mathrm{ml}$ & 15 & 46 \\
Sample $(\mathrm{n}=13)$ & 15 & $0(\mathrm{GM}=44.8)$ \\
Canadian and American standards & & \\
Geometric mean $(\mathrm{GM})$ of EF $\leq 35$ & $100(\mathrm{GM}=34.9)$ & \\
\hline
\end{tabular}

TC: total coliforms; THC: thermo-tolerant coliforms, EF: E. faecalis.

\subsection{Discussion}

\subsubsection{Microbiological Quality Control}

Microbiological analyzes of the bathing waters of "France" neighborhood and Azuretti-village beaches of Grand-Bassam showed the presence of microorganism types: total coliform, thermo-tolerant coliforms, E. coli, E. faecalis, Pseudomonas aeruginosa, yeast and the molds. Staphylococcus aureus, Salmonella sp, Shigella, sp Vibrio sp and Legionella were absent during the 13 months of study. For coliforms and enterococci, peaks were observed during two periods: January-February and June-September representing the periods of dry and rainy seasons. This presence of microorganism during the dry season could be explained by the massive attendance by beach swimmers during the holiday season [12]. The presence of swimmers is a source of water contamination. Recreational waters may be contaminated by direct excretion by bathers (vomits, urine, etc.), transport on body or growth within the filter bed and by waterborne pollutants from external sources (e.g., sewage, storm water, and agricultural runoff) [13]. During the rainy season, in addition to the pollution caused by bathers, the floods of the Ebrié Lagoon and the Comoé river are discharged into the Atlantic Ocean via the Vridi Canal [8]. The presence of E. coli and E. faecalis is indicative of other pathogenic fecal bacteria, viruses or protozoa $[14,15]$. Now, public water systems rely on bacterial indicators (i.e. coliforms) for monitoring water quality, and bacterial indicators have been shown to be poorly correlated with the presence of other microorganisms such as protozoa and viruses, which can be found in various water sources including finished drinking water [16] This could justify the presence of Pseudomonas and fungi [17]. The results of the factorial plan corroborate this presence of microorganisms (Tables 3 and 4). Their presence indicates a lack of environmental sanitation that exposes water resources to high levels of contamination of fecal bacteria [18]. These sprouts are not normally present in unpolluted waters and are generally considered as unable to grow in recreational waters [19].

\subsubsection{Physicochemical Quality Control}

The conductivity of the marine waters on the beaches of "France" neighborhood and Azuretti-village is also higher than the recommended value from 10 to $30 \mathrm{mS} / \mathrm{cm}$ [20]. These grades indicate high mineralization and may also be due to the inflow of contaminated water from human activities as contaminated discharges also increase water conductivity $[10,21]$.

The chemical pollution markers noted were ammoniums and phosphates. The presence of ammonium is a sign of a process of incomplete degradation of organic matter. It also comes from the excretion of living organisms and the reduction of organic nitrogen during the biodegradation of waste, without neglecting direct inputs of domestic and agricultural origin [22]. It is therefore an excellent indicator of water pollution. As for phosphate, its concentration is above the threshold value defined by WHO $(0.005 \mathrm{mg} / \mathrm{l})$. The phosphorus from which phosphates are derived is widespread in nature, plants, micro-organisms, animal wastes etc. Large quantities of phosphate are applied as fertilizers in agriculture, and runoff from these areas often contains elevated concentrations of phosphate [23]. These high levels appear to be related to agricultural runoff rich in fertilizer and also to the proximity of septic tanks [24].

\subsubsection{Comparison with Compliance Criteria for Bathed Water}

The microbiological and physicochemical results obtained were compared with the Ivorian, Algerian and Canadian standards of compliance with the bathing waters developed. According to the Ivorian reference system, bathing water is of satisfactory quality if the total and thermo-tolerant coliform numbers are less than 10,000CFU/100ml and $2,000 \mathrm{CFU} / 100 \mathrm{ml}$ respectively and if the $\mathrm{pH}$ is between 6 et 9 [7]. It appears that the bathing waters are conform throughout the season on Azuretti-village beach and a single non-compliance $(7.7 \%)$ is noted in August on the of "France" neighborhood. beach

Depending on Algerian standard, bathing water is of satisfactory quality if added to Ivorian criteria, the number of E. faecalis bacteria is less than 100CFU/100ml [25]. Based on that, the bathing waters conform to the total coliforms and heat-tolerant throughout the period of the study and not in accordance with E. faecalis during the months of January to February 2018 and from June to September 18 on both beaches. The Canadian and American standard stipulates that the geometric mean of E. faecalis must be less than 35 [14]. As a result, bathing waters have $54 \%$ of non-conformities in the "France" neighborhood and $62 \%$ of non-conformities in Azuretti-villages during January to February 2018 and from June to October 2018. With regard to the three standards, the 
Ivorian norm does not take into account E. faecalis. This Ivorian standard decree should be updated to take into account all the health risks for bathers.

\section{Conclusion}

The data collected during this study provided an overview of physicochemical and microbiological quality of the bathing waters of the Atlantic Ocean beaches in Grand-Bassam, Côte d'Ivoire. The physicochemical results obtained showed that these waters are heavily laden with minerals in Azuretti-village and the "France" neighborhood. Microbiologically, a presence of microorganisms was observed and was made up off total coliforms, thermo-tolerant coliforms, E. coli, E. faecalis, Pseudomonas aeruginosa, yeasts and molds. According to Algerian and Canadian standards, the waters of both beaches were of unsatisfactory microbiological quality during dry and rainy seasons. The pollution was most likely the result of the lack of sanitation and garbage collection services on the one hand and the presence of bathers and floods from the Ebrié lagoon and the Comoé river being rejected in the Atlantic Ocean via the Vridi canal. According to the three standards, only the Ivorian norm does not take into account the E. faecalis parameter. It is necessary to update the Ivorian norm to international standards and implement a health surveillance program at these two beaches to ensure the safety of bathers.

\section{Acknowledgements}

The Laboratory is grateful for Mrs Alphonse N'gbakou, Serge Dégny and Paul Akié for their technical contributions.

\section{References}

[1] Festy B, Hartemann P, Ledrans M, Levallois P, Payment P, Tricard D. Water quality. Environment and Public Health-Foundations and Practices. 2003; 333-68J. Clerk Maxwell, A Treatise on Electricity and Magnetism, 3rd ed., vol. 2. Oxford: Clarendon, 1892, pp. 68-73.

[2] Blanchet F, Soyeux E, Deutsch J-C, De Roeck Y. Impact of permanent or transient sanitation discharges on the quality of bathing water. Technical Sciences Methods. 2007; (3): 31-41.

[3] Errochdi S, El Alami M, Bennas N, Belqat B, Ater M, Fdil F. Study of physicochemical and microbiological quality of two north Moroccan hydrographic networks: Laou and Tahaddart. Journal of Mediterranean geography. 2012; (118): 4151.

[4] Anoh P. «Anoh Kouassi Paul et Pottier Patrick, dirs., 2008Coastal Geography of Côte-d'Ivoire: elements of reflection for an integrated management policy. CNRS-LETG UMR 6554 and IGT: Nantes-Abidjan, 325 p.» Book of Outre-Mer Geography Review of Bordeaux. 2010; 63 (251): 4859.

[5] Grand Bassam historical capital of Côte-d'Ivoire. [Internet]. [cited August 18, 2019]. Available on: http://www.hotel-restaurant-grand-bassam.com/Grand-Bassam .htmM. Young, The Technical Writer's Handbook. Mill Valley, CA: University Science, 198.
[6] Writing L. Côte d'Ivoire: Downgrading in hotels in Grand-Bassam, one year after an armed attack (REPORTAGE) - Connectionivoirienne.net [Internet]. Connectionivoirienne. 2017 [cited August 18, 2019]. Availableon: https://www.connectionivoirienne.net/2017/03/12.

[7] MSPS. Order No. 74/SPS/INHP setting hygiene standards in the sanitary control of swimming pools, bathing facilities and swimming pools open to the public. No. 74/SPS/INHP Dec 5, 1993 p. 4

[8] Bamba SB, Ouffoue S, Ble M, Metongo SB, Bakayoko S. Current state of the lagoon environment of the Vitre island (Grand-Bassam, Côte d'Ivoire): Physical, chemical and biologic aspects. Ivorian Journal of Science and Technology. 2008; 12: 7792 .

[9] Matini L, Moutou J, Kongo-Mantono M. Hydro chemical control of groundwater in an urban area, southwest of Brazzaville, Congo. Africa Science: International Journal of Science and Technology. 2009; 5 (1).

[10] Kanohin F, Otchoumou E, Yapo OB, Dibi B, Bonny AC. Physicochemical and bacteriological characterization of Bingerville groundwater. International Journal of Biological and Chemical Sciences. 2017; 11 (5): 2495509.

[11] Kaiser HF. The varimax criterion for analytic rotation in factor analysis. Psychometrika. 1958; 23 (3): 187200.

[12] Biswas K, Paul D, Narayan Sinha S. Prevalence of Multiple Antibiotic-Resistant Coliform Bacteria in the Water of River Ganga. Frontiers in Environmental Microbiology. 28 sept 2015; 1: 446.

[13] Yedeme K, Legese MH, Gonfa A, Girma S. Assessment of Physicochemical and Microbiological Quality of Public Swimming Pools in Addis Ababa, Ethiopia. TOMICROJ. 21 juin 2017; 11 (1): 98104.

[14] Guidelines for Canadian Recreational Water Quality-Third Edition Guideline technical document--Escherichia coli Water, Air and Climate Change Bureau, Healthy Environments and Consumer Safety Branch, Ottawa, Ontario.

[15] Joseph Fuh N. Assessment of Escherichia coli O157: H7 Contamination in Soil and Water Sources Proximal to Abattoirs Within Cross River State, Nigeria. Frontiers in Environmental Microbiology. 1 janv 2018; 4: 88.

[16] Reuben R, Gyar S, Aliyu Y. Physicochemical and Microbiological Parameters of Water from Rivers in Keffi, Central Nigeria. MRJI. 22 juin 2018; 24 (3): 112.

[17] Obaroh I, Yahaya T, Ibrahim U. Bacteriological Assessment of Soil Contaminated with Cement Dust. Environmental Microbiology. 1 janv 2016; 2: 147.

[18] Youmbi JGT, Feumba R, Njitat VT, Marsily G de, Ekodeck GE. Water pollution and health risks at Yaoundé, Cameroon. Reports [Internet]. 2013 [cited 3 Sept. 2019]; Available at: http://agris.fao.org/agris-search/searchdo? Record ID=US201600081225.

[19] Ashbolt NJ, Grabow WO, Snozzi M. 13 Indicators of microbial water quality. 2001.

[20] Rodier J, Bazin C. Water analysis: natural water, wastewater, seawater: chemistry, physico-chemistry, microbiology, biology, interpretation of results. Paris Dunod; 1996. 
[21] André Hade, Our Lakes: Knowing them to better protect them Internet]. [cited August 22, 2019]. Available at: https://journals.openedition.org/vertigo/5163.

[22] Derwich E, Benaabidate L, Zian A, Sadki O, Belghity D. Physicochemical characterization of the waters of the alluvial aquifer of the upper sebou downstream of its confluence with wadis fes. larhyss Journal P-ISSN 1112-3680/E-ISSN 2602-7828.

[23] Gloria Irenosen O. The Microbial Status and Physico-Chemical Pollutants Studies of Rivers Owan and Evbiobe in Edo State, Nigeria. SJAC. 2019; 7 (2): 57.
[24] Pollution from industrialized livestock production. Livestock Policy Brief (FAO) [Internet]. 2005 [cited 22 August 2019]; Available with: http://agris.fao.org/agris-search/search.do record ID $=$ XF2006424505

[25] Executive Decree No. 93-164 defining the required quality of bathing water. [Internet]. [cited 19 August 2019]. Available at: https://www.ecolex.org/en/details/legislation/executive-decretn-93-164-defining-quality-required-bath-water-lex-faoc04352 $0 /$ 